DOI: 10.20472/IAC.2020.055.001

\author{
KHALID AADA \\ University of Texas Rio Grande Valley, United States
}

\title{
REFLECTIVE TEACHING PRACTICES BETWEEN THEORY AND REALITY IN A DEMANDING SOCIETY
}

\begin{abstract}
:
Being a teacher implies enjoying the stages that students have to go through in order to learn; provide an environment conducive to learning; have an academic preparation to be successful. At various points in this process, unlearning is needed to relearn and make sense of a new experience. Being a teacher means recognizing that teaching is a transformative process for both students and teachers. The teaching activity can be defined as the set of actions, carried out inside and outside the classroom, aimed to promoting student learning in relation to the objectives and competencies designed in a planning and a specific institutional context. This leads us to reflect on the importance of developing a framework, as realistic as possible, of the methodology, objectives, content, assessment criteria and activities that are intended to be carried out with the students throughout the school year. But how far can we delimit the dimensions of this reflection? Why is reflection needed? what does the reflection represent for a teacher? Are we talking about an action, stage or a whole process? Why is it important to reflect on the act of teaching? What happens when a teacher begins to think and act not like a technical expert, but like a thoughtful professional? What does reflection in the teaching-learning process represent? Why does the professor need to reflect, invent, and differentiate?

The main purpose of this work is to present a pedagogical tool that could help to see and understand the teaching-learning process beyond a simple interaction between the professor and his students, and thus to contribute to the improvement of the study planning. In this article, readers and teachers interested and passionate in this field of education will focus their attention to the importance and the need of being a professional reflexive not only in a narrow perspective but at a global scope, including the way how students learn from the cognitive dimension, especially those who need more assistance. Is it a complex process? Yes, but to reach that deep understanding of what is happening will have the benefit to take the teaching-learning vision from practice dimension to a significative purpose, and would complement any didactic training that teachers perform to make practical decisions, allowing them to reach the established objectives.
\end{abstract}

\section{Keywords:}

Educational practice, Professional reflective, Reflection, Reflective teaching, Self-reflection

JEL Classification: 129 


\section{Introduction}

What does a reflection or a self-reflection mean? What does it consist of in favor of educational practice and why has it arisen? In the last decade, the expressions reflective teaching and reflective teacher have become central themes to the teaching reform and teacher training worldwide.

In the midst of this new dimension, confusion has been generated regarding the meaning of the expression reflection, such as teacher research training and restructuring. It has reached the extreme that the set of existing beliefs in the educational community about teaching, learning, teaching and social order, has been incorporated into the discourse on reflective practice, which stands the meaning of the term reflection on an exponential scale.

Garcia (2009) mentions that as the educator reflects on his work, explains it, understands it, intervenes in it and achieves success, acquires prestige and discovers the role that teaching work plays in social change. The expression "stop and think" invites the teacher too make a constant evaluation of the action process within the classroom, the procedures used and the impact caused. On the other hand, Pruzzo (2001) affirms that reflection unleashes critical processes with which the teacher manages to understand his own practice, interprets the knowledge that sustains it and the cultural conditions that can distort it; while, Blández (1996) considers that reflection is a way of thinking, which implies deepening, analyzing, studying, meditating on "something" carefully, with attention and care. On the other hand, he argues that reflection implies questioning everything that is done and presents an open and understanding mind towards criticism.

Reflection also means the recognition that the production of knowledge - based on an adequate teaching process - is not the exclusive property of educational research and development centers; the recognition that teachers also have theories, which can contribute to the constitution of a codified base of knowledge about teaching. From the perspective of the reflective professional, it is the process of understanding and perfecting one's own teaching exercise by reflecting on one's own experience; it is a process of learning to teach throughout the teacher's teaching career.

For Dewey (1989), reflective action involves an active, persistent and careful consideration of any belief or practice in light of the foundations that sustain it and the consequences to which it leads. According to Dewey, reflection is not a set of specific steps or procedures that teachers have to follow. It is, instead, a way of facing and responding to problems, a way of being as a teacher. Reflection is also a wide broader process than a logical and rational problem solving. Reflection implies intuition, emotion and passion.

What happens when a teacher begins to think and act - not like a technical expert, but like a thoughtful professional? His reflection for an action's dimension is positively reflected in the improvement process.

The teacher tries to listen to his students. We may ask ourselves for example: how is the student thinking about this? What does the confusion mean and why is it? What does the student master? But if we really listen to a student, we would land an action plan with ideas that transcend our framework. We may want, for example, to focus for a while on the nature of a student's error or confusion. Why does he write " $27+27+414$ "? When the teacher begins to understand how students think on their homework assignment, he can come up with new questions, new activities for students to better practice, and new ways to help them to have a better understanding to do an addition equation.

The program or the content of the lesson, then, must be left aside, or it must also become an approximate basic action plan, where the teacher develops a variety of activities that aim to the understanding of the problems and the progress of some particular students.

The Curriculum becomes an inventory of comprehension and skill topics to apply to, rather than a set of data that needs to be learned. Different students present different phenomena of understanding and action. Each student builds his own universe, whose potentials, problems and work rhythm must be appreciated when the teacher reflects from an action dimension on the design 
of his work. The freedom to reflect, invent and differentiate would break the institutional order of space and time. It the teacher has to direct - in some way - the work of thirty students in a classroom, how can he really listen to each of them? If you are rigorously responsible for sticking to a sequence of hour-long periods to cover specific subject units in a subject, then you cannot follow the rational of your reflection from an action plan. Classes should be small, or easily divisible into smaller units, and each teacher should be free to introduce variations in the institutional program. On the other hand, teachers must broaden the scope of their interest in students' progress. What do they know to do outside of the school, becomes deeply interesting to the teacher; it suggests the intuitive competencies to build his teaching process. Reflective teachers constantly wonder why do they do what they do in class. Their actions carry intellectual openness, responsibility and sincerity.

In this sense, other processes such as assessment acquire new meanings. There is a general shift when we search for objectives' measures pointed to student progress, administered in a centralized way, towards qualitative, independent judgments, and narrative records of the experience and performance of learning and teaching process. For this, the assessment stage will be present from the very beginning of the planning, which means that before starting the action, it is determined how the implementation process will be assessed and monitored. Reflective practice leads the teacher to consider it necessary to use supervision strategies and techniques that demonstrate the good quality of the undertaken course of action; the instruments that show the effects derived from the action, both those sought and unforeseen; and, a series of tools that allow observing what happens from different angles or points of view. That is, to be interested and consider the feedback of the environment when observing the changes.

\section{Reflection within a process of didactic transposition}

On the other hand, this reflection stage is efficient when it goes along with a didactic transposition process, which is not limited to a single didactic act, but also involves an interactive and symbolic activity where it is transmitted, learned and shared; It is a complex process that requires the intervention of the teacher, who has several interpretive schemes to produce new content or meaning in the thematic aspects included in the prescribed study plan.

Its complexity consists of the fact that the teacher is influenced by many variables, such as his initial training, professional habits, personal and specific relationships with science and school culture, definitions of educational objectives, personality in front of a group, institutional vision, preferences, level of resistance to changes ... etc.

The role of teachers in this whole process is very crucial due to their desire to improve the teaching process on a daily basis and lead their students to understand the role and importance of knowledge for the development of their personality. However, the intervention of teachers could lead to the enrichment or impoverishment of the study plan, in its reinterpretation, which does not always appear as an explicit intention, but rather as a kind of "prepared improvisation" (Perrenoud, 1994).

Both Shulman and Chevallard (1987) have developed a theoretical framework - reaching their own epistemological basis - that allows to explain and describe the importance of knowing how to land the basis knowledge of teaching to the benefit of student learning, beyond the literal transmission of what is written and previously designed in a study plan. Both approaches bring to light the relevance of having the ability to transform knowledge in different ways - didactically - adapted to the variety of educational environment that each teacher faces. The knowledge of reference and the knowledge that is taught are not identical since they produce transformations in different instances (Bolivar 1993). Both theories compromise the training of teachers in specific didactics.

In this sense, the ability to transform knowledge requires something more than substantive and syntactic awareness and control of a discipline; It requires at the same time knowledge of students and learning objectives/outcomes, the curriculum and context, and pedagogy (Bolivar, 2013).

From this conception, several authors recognize the importance of the need to develop interpretative and deliberative curricular capacities and professional expertise to make an active and creative use of both disciplinary knowledge and the curriculum itself. Designing training programs for teachers 
means the development of strategies whose objective would be to create, adapt, transform and land the study plan and disciplinary knowledge to the educational context faced. As Shulman (1987: 9) defines it well: "A professor is a member of an academic community. He must understand the structures of the subject taught, the principles of conceptual organization, as well as the principles of inquiry that help answer two types of questions in each domain: What are the important ideas and skills in this domain of knowledge? And in what way do those who generate knowledge in this area incorporate new ideas and discard superfluous or deficient ones? That is, what are the rules and procedures for good academic and research knowledge? "

This leads us to reflect on the relevance of the active intervention of the various actors in the construction of knowledge through the school curriculum. In other words, the didactic process requires a constructivist dimension, because the students' knowledge is not the result of passive reception, but of their cognitive activity.

\section{Educational technology in the process of educational reflection}

A reflective teacher also needs a type of educational technology that does more than just extend their training and practice process. Most interesting to him is an educational technology that helps students to become aware of their own intuitive understandings, to lead to cognitive confusions and to explore new directions for understanding and action.

Currently, IT tools increasingly represent a strong presence, progressively incorporating different resources for teachers as shown in various reports (Hawkins, 2010; Durall et al., 2012; Johnson et al., 2013): semantic web, internet, learning analytics, cloud computing, MOOC, personal learning environments, social networks, etc. All this allows teachers to have a true digital ecosystem in the contexts of their training.

However, carrying out this new style of educational interaction implies the need to master new pedagogical structures and significantly consider the impact on the cognitive processes of students. It is worth mentioning that the tools used are not limited only to providing work information, but become a matter of thought, favoring the development of various processes whose emphasis is on the notable differences between learning with technologies and learning based on traditional procedures.

Within this context, it is important to mention that tools - in addition to being instruments - respond to the recreation that is made of the world, thus becoming agents of change, in the same way that technological innovations do not happen in the abstract. As stated by M. Castells (2000), "they depend on the context, the state of knowledge, the institutional, industrial, economic environment...". Other authors such as R. McChesney (2013) cited by Trujillo (2016) emphasize that technology also has a political nature that is designed when analysis are carried out on it, forgetting the contextual conditions in which The forms of power and the commercial interests around them emerge and develop, sometimes these elements being more relevant than the design or use of technologies. In a similar line of thought, Burbules and Callister (2001) point out that "tools can have certain established uses and purposes, but they frequently acquire other predictable ones and generate new, unpredictable effects [...].

\section{Reality of reflection when it's not considered serious}

But what happens when the reality of reflection is perceived as unproblematic in an everyday school context? The own vision of reality of each teacher and professor serves as a barrier against the recognition and experimentation of different points of view. Teachers who do not reflect on their duties on a daily basis, focus their efforts on discovering the most effective and efficient means to achieve the ends and solve problems largely defined by others for them. They lose sight of the objectives and ends towards which they direct their work, and become mere agents of third parties. 
Any problem can be approached in different ways. Non-reflective teachers automatically accept the view of the problem that is generally adopted in a given situation.

It is worth mentioning that the reflection revealed in teaching as a process of criticism and development of the social conditions that shape the teaching experiences, requires periodically to be ready and open-minded, in both its theoretical and practical dimensions, to critical analysis and discussion, in order to become aware of the contradictions and weaknesses that are exposed between different angles, and thus be able to think about a concrete and significant development of teaching practice.

As a proposal to carry out a reflection exercise on teaching practice:

\begin{tabular}{|c|c|}
\hline \multirow[t]{2}{*}{ Positive attitude } & Learn, Understand and Discover \\
\hline & $\begin{array}{l}\text { - What makes me special as a teacher? } \\
\text { - What are my core qualities? }\end{array}$ \\
\hline $\begin{array}{l}\text { Beyond any description or } \\
\text { judgement }\end{array}$ & $\begin{array}{l}\text { Replace lables like Good or Bad with } \\
\text { Why or What do I learn if I do the same } \\
\text { from another angle/perspective? }\end{array}$ \\
\hline Search for specific data & Do not reflect without having evidence. \\
\hline \multicolumn{2}{|c|}{$\begin{array}{l}\text { Trying to analyze various aspects of teaching practices in a single class and making } \\
\text { the decision to change them without reflection would be counter-productive }\end{array}$} \\
\hline $\begin{array}{l}\text { Set specific goals } \\
\text { Deep thinking on the issue }\end{array}$ & $\begin{array}{l}\square \text { Reflecting step by step on a series of } \\
\text { different classes, student assignments, } \\
\text { assessment strategies.....etc } \\
\square \text { the same issue to come up with new } \\
\text { solutions derived from a different } \\
\text { understanding to the problem itself. }\end{array}$ \\
\hline $\begin{array}{l}\text { Analyse the issue from different } \\
\text { perspectives/points of view. }\end{array}$ & $\begin{array}{l}\text { Share once own reflections with classmates or } \\
\text { other teachers who are facing concerns. }\end{array}$ \\
\hline
\end{tabular}

\section{Source: Author}

\section{Conclusion}

Finally, and as highlighted in both researches of this nature and the experiences of the act of teaching-learning, educational practice is complex. Teachers are expected to prepare programs, to select up-to-date content, to propose appropriate and innovative learning activities, to pose critical and interesting questions, to propose a variety of teaching resources, to effectively assess learning, to consider each student and the group as a whole, among multiple issues. Many times, the participation of the teacher when thinking about pedagogical changes is limited to the implementation of what theorists and experts have developed, and they are only asked to be executors of the actions developed by others.

As mentioned by Schön (1998) together with Perrenoud (2004), the current that develops the ideas of the teacher as a reflective professional and as a researcher of his own actions, recognizes that no educational change is possible if there are not teachers in dialogue and interaction between their 
practices and theories, such as the belief systems that are produced from them. One of the basic keys to the effective development of any curricular design is an active teacher committed to transformation actions.

\section{Referencias}

Blández Ángel J. (1996). Action research a challenge for teachers "Practical guide for work groups, seminars and research teams. Spain: INDE publications.

Burbules, N. \& Callister, T., (2001). Risks and promises of the New Information Technologies, Granica, BuenosAires (2001).

Castells, M., (2000). The age of information. Vol.1. The Red Society], Alianza, Madrid.

Contreras Domingo, J. (1994) Teaching, curriculum and teachers. Akal University. Madrid

Dewey, J. (1989) How we think. Cognition and human development, Paidós. Barcelona.

Durall, E et al (2010): Technological Perspectives: Higher Education in Latin America 2012-2017, Austin, Texas, The New Media Consortium

Elliot, J. (2000). Educational change from action research. Morata. Madrid

Gracia M. J. (2009). Integrated professionalism. A new way of being an educator. Mexico. National Pedagogical University. Plaza y Valdez Editores.

Hawkinks, R. (2010): 10 Global trends in ICT and education. Disponible at: https://blogs.worldbank.org/edutech

Johnson, L. et al. (2013): Technological perspectives: higher education in Latin America 20132018. A regional analysis of the Horizon Report, NMC, Austin, Texas, The New Media Consortium.

Liston, D. y Zeichner, K.M. (1993) Teacher training and the social conditions of teaching. Morata. Madrid Perkins, D. (1992) The intelligent school. Gedisa Editorial. Barcelona

Perrenoud P. (1994). Student occupation and meaning of schoolwork. Paris : ESF.

Perrenoud, P. (2004) Ten new skills to teach. Editorial Graó. Barcelona

Pruzzo, V. (2001). The Transformation of teacher training: from traditional practices to new assistantships, Buenos Aires: Editorial Espacio.

Schön, D. (1998) The thoughtful professional. Paidos. Barcelona

Shulman, L.S. (1986a). Those who understand: knowledge growth in teaching. Educational Researcher, 15 (2), 4-14.

Shulman, L.S. (1987). Knowledge and teaching: Foundations of the new reform. Harvard Educational Review, 57 (1), 1-22. Edic. cast.: Conocimiento y enseñanza: fundamentos de la nueva reforma. Profesorado. Revista de Currículum y Formación del Profesorado, 9 (2), 2005.

Shulman, L.S. (1988b). The dangers of dichotomous thinking in education. En P.P. Grimmet y G.L. Erickson (eds.), Reflection in teacher education. Nueva York: Teachers College Press, 3139.

Stenhouse, L. (1985) Investigation and development of curriculum. Morata. Madrid.

Trujillo, M., C., (2016). Learning with new technologies: a look from Neuroscience and Cognitive Psychology. III Ibero-American Conference on Educational Innovation in the field of ICT. Las Palmas de Gram Canaria 17-18.

Wilson D. (1999) Organizational inquiry: support for schools and individual development - in Closing the gap: First meeting of Latin American tutors online - Harvard University Graduate School of Education - Project Zero - July 2002 - Miami 